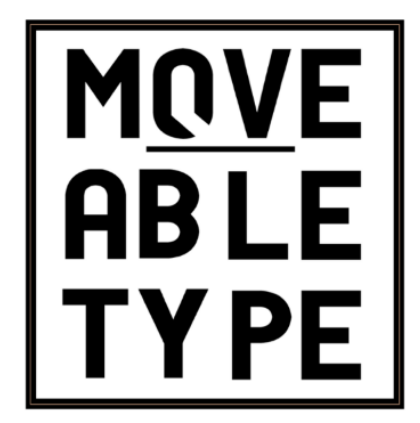

Article: Paradise Lost and the Poetics of Encyclopedism

Author[s]: Hazel Wilkinson

Source: MoveableType, Vol. 7, 'Intersections' (2014)

DOI: $10.14324 / 111.1755-4527.058$

MoveableType is a Graduate, Peer-Reviewed Journal based in the Department of English at UCL.

(C) 2014 Hazel Wilkinson. This is an Open Access article distributed under the terms of the Creative Commons Attribution License (CC-BY) 4.0https://creativecommons.org/licenses/by/4.0/, which permits unrestricted use, distribution, and reproduction in any medium, provided the original author and source are credited.

\title{
¿UCLPRESS
}




\section{Paradise Lost and the Poetics of Encyclopedism}

Milton's Paradise Lost is extensively involved in the discourse seventeenth-century natural philosophy, a fact that has received considerable critical attention. ${ }^{\mathrm{I}}$ However, readers alert to this aspect of the poem have tended to see certain passages as pronouncements of a theory of natural philosophy. This tendency has obscured the important fact that the type of seventeenth-century scientific discourse in which Milton participated rejects the idea of the definitive pronouncement. Stephen Fallon has argued that Milton's monism amounts to a consistent philosophy of matter; ${ }^{2}$ I will argue, not that Milton's philosophy is inconsistent, but that by framing it in the discourse of encyclopedism, Milton deliberately undermined the notion of a unifying or conclusive epistemology. I will draw parallels with Francis Bacon and Robert Burton to show that the discourse of encyclopedism in Paradise Lost makes all knowledge in the poem vitally preliminary, with the implication that the poem should be read, at all times, as a work in progress.

1 Notably Harinder Singh Marjara, Contemplation of Created Things (Toronto: Toronto University Press, 1992) and Karen Edwards, Milton and the Natural World (Cambridge: Cambridge University Press, 1999).

2 Stephen Fallon, Milton Among the Philosophers (Ithaca: Cornell University Press, 1991). 


\section{Milton Among the Encyclopedists}

'The [Renaissance] encyclopedia,' claims Neil Kenney, is 'conceived ... as a circle of learning to be internalised within the mind of the well-rounded or exceptional individual'. ${ }^{3}$ In light of this point, the argument might be made that Robert Burton's Anatomy of Melancholy ( $162 \mathrm{I}$ ) and Francis Bacon's Novum Organum ( 1620 ) should not be called encyclopedias, since both works deny the finite conclusiveness of the possibility that an individual might 'internalise' knowledge. The Burtonian and Baconian methods are perhaps better understood as subgenres of encyclopedism which turn the 'circle of learning' inside-out-that is, their works cast the circle of learning so wide that it encircles the individual and cannot be satisfyingly internalised.

Jonathan Sawday has suggested that 'in the eighteenth century, [Burton's] Anatomy became virtually unreadable'. ${ }^{4}$ The Anatomy fails to mark itself as definitive, conclusive, or even finished, in the way that eighteenth-century readers came to expect from printed texts: instead it is as 'evanescent, transient, ... [and] provisional' as speech. ${ }^{5}$ Sawday suggests that though we are still predisposed to see the provisional nature of the Anatomy as a peculiarity,

Burton 'was actually at the vanguard of the scientific movement of the earlier seventeenth

3 Neil Kenney, The Palace of Secrets: Béroalde de Verville and Renaissance Conceptions of Knowledge (Oxford: Clarendon, 1991), p.25.

4 Jonathan Sawday, 'Shapeless Elegance: Robert Burton's Anatomy of Knowledge', in English Renaissance Prose: History, Language, and Politics, ed. by Neil Rhodes (Tempe, AZ.: Medieval and Renaissance Texts and Studies, 1997), pp.173-202.

5 Ibid., p.185. 
century'. ${ }^{6}$ Burton's work was not 'the result of a mind no longer in control of words', but rather

it 'fashioned ... a flexible morphology so that new information could be reincorporated into the

whole without the necessity of dismantling the entire structure'. 7 Burton's flexible morphology

in no way aims to be definitive. Neil Kenney has argued that in approaching Renaissance

encyclopedic texts we should abandon modern conceptions of encyclopedias as 'certain,

objective, and compartmentalized'. ${ }^{8}$ Burton's flexible morphology works on the presumption,

alien to modern notions of encyclopedism, that the genre should 'not only organise existing

facts but also ... leave room for new ones that will be discovered'. ${ }^{9}$ Burton's Anatomy is not a

typical encyclopedia, but its flexible morphology is paradigmatic of a certain type of open-

ended Renaissance encyclopedic discourse.

Like Burton's Anatomy, Francis Bacon’s Novum Organum attempts to establish a

discourse of natural philosophy that 'leave[s] room for new' enquiry. Bacon's preface begins:

Those who have presumed to make pronouncements about nature as if it were a closed subject, whether they were speaking from simple confidence or from motives of ambition and academical habits, have done very great damage to philosophy and the sciences. They have been successful in getting themselves believed and effective in terminating and extinguishing investigation. ${ }^{\circ}$

6 Ibid., p.175. Sawday uses 'earlier seventeenth century' to mean the period from the 1620 s to the publication of Locke's Essay Concerning Human Understanding, i.e. 1689.

7 Ibid., pp. 189, 200.

8 Kenney, The Palace of Secrets, p.36.

9 Ibid., p.32.

10 Francis Bacon, Novum Organum (1620), ed. by Lisa Jardine and Michael Silverthorne (Cambridge:

Cambridge University Press, 2000), p.27. All subsequent references are to this edition. 
Traditional scientific language is reductive, it 'terminat[es] and extinguish[es] investigation',

whereas Bacon's new instrument asks the reader not 'to be content with what has been

discovered, ... but to penetrate further'. ${ }^{\text {I }}$ Bacon's aphoristic discourse, like Burton's flexible

morphology, seeks a position 'between the ostentation of dogmatic pronouncements and the

despair of lack of conviction'. ${ }^{2}$ Stephen Clucas has described Bacon's intent as 'to promote

and invigorate dissatisfaction with contemporary philosophical discourse and its concepts and

create new epistemological grounds from which to interrogate.. ${ }^{13}$ Bacon essentially announces

the death of the conclusion, stipulating that all discourse be viewed as liminal, as a threshold

opening on to 'new epistemological grounds', rather than an end in itself.

\section{Paradise Lost \& the Burtonian 'if'}

The Baconian and Burtonian methodologies described above pervade Paradise Lost. In the Anatomy II.ii.3 (Air Rectified, With a Digression of Air), Burton imagines himself 'as a long-

winged hawk, ... still soaring higher and higher till he be come to his full pitch, and in the end ... comes down amain'. Like the hawk, Burton will 'awhile rove, wander round about the

11 Novum Organum, 'Preface', p.30.

12 Ibid., p.27.

13 Stephen Clucas, “'A knowledge broken”: Francis Bacon's Aphoristic Style', in English Renaissance Prose, ed. by Neil Rhodes (Tempe, AZ.: Medieval and Renaissance Texts and Studies, 1997), 147-72, p.163. 
world, mount aloft to those ethereal orbs and celestial spheres, and so descend to my former

elements again'. ${ }^{14}$ This bears comparison with Milton's address to Urania:

above the Olympian hill I soar,

Above the flight of Pegasean wing

...Up led by thee,

Into the Heaven of Heavens I have presumed,

An earthly guest, and drawn empyreal air,

Thy tempering. With like safety guided down,

Return me to my native element ${ }^{15}$

The similarity between the two passages is more than coincidental: Milton's celestial

perspective is not simply a trope for literary or spiritual inspiration, but a participation in a

seventeenth-century way of studying the natural world. Comparing Paradise Lost to Robert

Hooke’s Micrographia ( 1665 ), Lara Dodds finds that 'like the microscope, Paradise Lost

reveals a world quite other than our own'. ${ }^{16}$ The extreme perspectives of microscope and

telescope, by which Milton is 'up led' and 'guided down', create what Dodds calls

'estrangement', a process which forces a reconsideration of the relations between things.

When Burton roams the globe as an eagle, he poses scores of questions, from the

geographical - 'The pike of Teneriffe how high is it?' ${ }^{17}$ - to the biological—'do [Muscovite

14 Robert Burton, The Anatomy of Melancholy (1621) ed. by Holbrook Jackson (New York: New York Review of Books, 2001), II.ii.3, pp. 34-5. All subsequent references are to this edition.

15 John Milton, Paradise Lost, ed. by Alastair Fowler (London: Longman, 2007), VII.3-16. All

subsequent references are to this edition.

16 Lara Dodds, 'Rhetorical Microscopy in Paradise Lost', in Milton Studies 47 (2008): 96-117, p.98.

17 Anatomy, p.37. 
birds] sleep in winter, like Gesner's Alpine mice? ${ }^{\text {' }}{ }^{8}$ Each question creates an unfulfilled

potential, a problem to be solved, revealing mysteries rather than certainties, estranging the

natural world. When Milton soars 'above the Olympian hill' he too makes the world appear

strange. Raphael's conversation with Adam is likewise conducted in Burtonian questions:

What if the sun

Be centre to the world, and other stars

By his attractive virtue and their own

Incited, dance about him various rounds?

...six thou seest, and what if seventh to these

The planet earth, so steadfast though she seems,

Insensibly three different motions move?

...What if that light

Sent from her through the wide transpicuous air

To the terrestrial moon be as a star

Enlightening her by day, as she by night

This earth? Reciprocal, if land be there,

Fields and inhabitants. ${ }^{19}$

In his notes on these lines, Alastair Fowler cites the Anatomy II.ii.3, which reads 'if the earth

move, it is a planet, and shines to them in the moon, and to the other planetary inhabitants, as

the moon and they do to us upon the earth'.2० The Burtonian 'if' (almost fifty clauses begin

'if...' in the Digression of Air) marks Raphael's speech as conjecture. Raphael provides Adam

with questions, not answers, thrusting him into the uncertain space of 'what if?', where

discourse is proposition, not conclusion. Joanna Picciotto has described encyclopedic

18 Ibid., p.38.

19 Paradise Lost, VIII.122-144.

20 Anatomy, p.53 
discourse as 'the production of alien experiences of the known world'. ${ }^{21}$ The potential of Raphael's 'What if?' is quite literally 'the production of alien experiences': if the universe is heliocentric, and if the earth is the seventh planet, might there be 'inhabitants' on the moon?

\section{Paradise Lost \& Baconian 'instances'}

'The subtlety of Nature', writes Bacon in the Novum Oragnum, 'is far greater than that of the sense and the understanding, so that all our beautiful speculations and guesses and controversies are absurd. ${ }^{22}$ At face value this sounds like an indictment of speculative discourse like the Burtonian 'if..., but what appears a criticism is actually a statement of a vital precondition for discussing the natural world. Karen Edwards makes a similar point in relation to Milton, which throws light on Bacon's statement:

There is nothing "natural" without the mediating work of the human understanding. But precisely because it is necessary to construe in order to understand, we are not limited to those myths that we have produced before us; we can re-form our myths. ${ }^{23}$

If nothing is to be accepted as fact, all 'beautiful speculations' should be considered 'absurd', but this is not to say they should be dismissed without consideration. '[T]he subtlety of nature

21 Joanna Picciotto, 'Reforming the Garden: The Experimentalist Eden and Paradise Lost', in English Literary History 72 (2005): 23-78, p.26.

22 Novum Organum I.10, p.34.

23 Edwards, Milton and the Natural World, p.114. 
is far greater than ... the understanding', but since the understanding is, as Edwards makes

clear, indispensable, the only viable method, to Bacon, is proliferation of 'speculations': if the absurdity of resting at a single speculation is acknowledged, multiple 'speculations' can be allowed to build up to a plural 'sense and ... understanding'. Burton's practice of stacking question upon question, then, is not alien from the Baconian method, and the absurdity of the definitive answer is fully acknowledged by the Burtonian 'if'.

Bacon summarises his method in the Novum Organum:

The investigation of forms proceeds thus: a nature being given, we must first of all have a muster or presentation before the understanding of all known instances which agree in the same nature, though in substances the most unlike. And such collection must be made in the manner of a history, without premature speculation, or any great amount of subtlety. For example, let the investigation be into the form of heat. ${ }^{24}$

To determine what 'heat' is, every substance that can be said to have or lack heat must be listed. To compile such a list is the work of the "natural and spontaneous movements of the mind'. ${ }^{25}$ 'Premature speculation', that is, preconception or expectation, is forbidden, and heat is not 'understood' but rather 'all known instances' are presented 'before the understanding'.

The 'understanding' takes a passive role -it mustn't interpret or speculate, but remain open to more and more 'instances'. Some of Bacon's 'instances' of heat are

24 Novum Organum II.11, p.110.

25 Ibid., 'Preface', p.28. 
I. The sun's rays...

2. The sun's rays reflected...

3. Fiery meteors.

4. Burning thunderbolts.

5. Eruptions of flame from hollows in mountains. ${ }^{26}$

A similar listing of 'instances' is employed by Milton in his description of Satan's progress through chaos:

so eagerly the fiend

O'er bog or steep, through straight, rough, dense, or rare,

With head, hands, wings, or feet pursues his way,

And swims or sinks, or wades, or creeps, or flies. ${ }^{27}$

Fowler explains the asyndeton here as 'Miming the atomised, unstructured state of chaos, and its hectic confusion of sense-data'. ${ }^{28}$ This is only a partial explanation. With the Novum Organum in mind, the passage becomes not so much a chaotic 'confusion of sense-data' as a Baconian enquiry into the possible substance of chaos. Milton is re-forming chaos with each word. Just as heat can be a meteor, and it can be a volcano, so chaos can be a bog, and a steep, it can be rough, and dense. These possibilities are presented by Milton as if to the Baconian understanding, which must accept them 'without premature speculation'. Attempting to understand the passage as a cohesive picture results in a 'hectic confusion of sense data'.

About Paradise Lost in general, Edwards concludes that 'Reading such a text requires the humility to submit one's conclusions to continual reassessment; without it, the fragments of

26 Ibid., II.11, p.110

27 Paradise Lost II.942-50.

28 Alastair Fowler (ed.), Paradise Lost, p.157n. 
the world's text are cemented into immobility. ${ }^{29}$ 'Continual reassessment' is the key to

reading Milton's chaos. The 'hectic confusion' of instances should not be explained away as a

special effect: it is symptomatic of a Baconian mode of enquiry which eschews cohesion.

It becomes even more apparent that a so-called 'hectic confusion of sense-data' is not simply a way of mimicking chaos when we realise that this tactic is employed throughout

Paradise Lost. Satan, for example, is a wolf, cormorant, lion, tiger, toad, and a horse in Book IV alone. $^{3^{\circ}}$ The earth is one minute a 'wilderness ... grotesque and wild', the next a 'sylvan scene', then 'Mozambic', with 'Sabean odours', and yet again a pastoral sheep fold, all within fifty lines. ${ }^{31}$ In considering the idea of 'information overload' Jonathan Sheehan finds that Renaissance encyclopedists 'refused to enforce levels of priority between different ... interpretive possibilities'. ${ }^{32}$ Milton's apparently hectic descriptions are not a failure to build a cohesive picture, but an encyclopedic discourse that refuses to 'enforce levels of priority' between the different possible ways of looking at his subjects. The most viable reading strategy for coping with the resultant information overload in Paradise Lost is that proposed by Edwards-to 'submit one's conclusions to continual reassessment'-that is, treat every part of the text as preliminary.

29 Edwards, Milton and the Natural World, p.98.

30 See Paradise Lost IV.183, 196, 402, 403, 800, 858.

31 Ibid., IV.135-5, 140, 161-2, 185.

32 Jonathan Sheehan, 'From Philology to Fossils', Journal of the History of Ideas 64 (2003): 41-60, pp.46, 51 . 


\section{'If true, here only'}

Having situated Paradise Lost in the context of an encyclopedic discourse that denies the act

of concluding, I shall show how pervasive this discourse is throughout Paradise Lost. So far it has been seen only in passages that bear direct resemblance to extracts from Burton and Bacon, but the poetics of encyclopedism can be said to underpin the whole poem. I use the term poetics of encyclopedism not just because Paradise Lost transposes Baconian and Burtonian encyclopedism into verse, but because encyclopedic discourse is enacted by the very mechanisms of Milton's verse, which explores scientific ideas in different ways to the prose of Bacon or Burton.

Milton frequently uses the line break to explore Baconian and Burtonian possibilities:

Men called him Mulciber; and how he fell

From heaven they fabled, thrown by angry Jove

Sheer o'er the crystal battlements: from morn

To noon he fell, from noon to dewey eve,

A summer's day: and with the setting sun

Dropped from the zenith like a falling star,

On Lemnos the Aegean isle: thus they relate,

Erring; for he with this rebellious rout

Fell long before. ${ }^{33}$

33 Paradise Lost, I.740-48 
In 'Thus they relate, | Erring' the pause between the two lines opens out the space between fact and fiction, truth and error, conclusiveness and inconclusiveness. What is striking is that Milton relishes the erroneous story. Paradise Lost never seeks to deny the existence of error, rather it acts out the processes by which error is created, sustained, and finally refuted. Until 'Erring', the reader could be forgiven for taking the story of Mulciber's fall at face value.

However, 'Erring' drives home the implications of the initial 'fabled', reinforcing the necessity of the delicate reading practice Karen Edwards described as 'the ability to submit one's conclusions to continual reassessment'. The line break between 'relate' and 'Erring' vitally forestalls the collision between a fact and its undoing, relishing the space of multiple possibilities before the second half of the sentence reveals the fable to be a Baconian absurd speculation. Paradise Lost is not simply in the business of correcting error: the poem's larger project is to demonstrate how pervasive error is, and to show that all conclusions must be interrogated and considered preliminary.

The expansion of the moment in which 'beautiful speculations' hang in the balance between truth and error is a common feature of Paradise Lost:

Groves whose rich trees wept odorous gums and balm, Others whose fruit burnished with golden ring Hung amiable, Hesperian fables true, If true, here only, and of delicious taste. ${ }^{34}$

34 Ibid., IV.250. 
In the encyclopedic discourse of Bacon and Burton, the only place in which any so-called fact is true is in the space between the presentation of one thing before the understanding, and the next. In this instance, 'Hesperian fables' can be true only in Eden, which ultimately proves to be a temporary space. The phrase 'Hesperian fables true...' appears to make a statement of fact-Hesperian fables, it seems to say, are true-and Milton extends and prolongs this possibility over the white space of the line break, allowing it to exist in the transition from one line to the next, before exposing it to absurdity. Hesperian fables are not only true 'here [i.e Eden] only', but true 'here [i.e in the moment of speculation] only'.

\section{'Had' and 'had not'}

At certain key moments Paradise Lost holds multiple possibilities and historical situations in balance. Not only are errors made momentarily true, alternative courses of Biblical history are imagined, as in the depiction of Satan falling through chaos:

He drops

Ten thousand fathoms deep, and to this hour Down had been falling, had not by ill chance 
The strong rebuff of some tumultuous cloud

Instinct with fire and nitre hurried him

As many miles aloft. ${ }^{35}$

The formula 'had ... had not' considers the possibility of something that didn't happen. Again the line break comes in to play in opening up this otherwise redundant possibility: by placing 'to this hour' at the end of the line, Milton plays with the possibility that Satan is still falling in this (the reader's) time, before 'had not by ill chance...' closes off this possibility. Antony Welch writes that Milton's 'pivoting between space and time, ... [manipulates] the physical barriers of time and space that thwart the ability of "mortal men" to appreciate the magnitude of either distance. ${ }^{36}$ There is a deliberate confusion of time and space in 'to this hour | Down had been falling', because it forces the reader to extend 'Ten thousand fathoms' to some even greater distance which would allow Satan to fall from prehistory to the present day. Our understanding, as Welch says, is deliberately 'thwart[ed]' by the 'pivoting' of space and time by which Milton hurls Satan through chaos, potentially endlessly. The momentary enabling of the impossible enacted by 'had ... had not' necessitates Edwards's 'continual reassessment'. It is like the Burtonian 'if', which alienates the familiar, or the Baconian absurd speculation which must be presented before the understanding, but not lingered upon.

35 Ibid., II.933-38.

36 Anthony Welch, 'Reconsidering Chronology in Paradise Lost', in Milton Studies 41 (2002): 1-17, p.3. 
The formula 'had ... had not' recurs again and again in Paradise Lost. In Book II, as

Satan and Death prepare to fight, 'great deeds | Had been achieved, whereof all hell had rung,

| Had not...' Sin intervened. ${ }^{37}$ Similarly in Book IV 'dreadful deeds | Might have ensued; | ...

All the elements $\mid$ At least had gone to wreck | ...had not' God tilted 'his golden scales'. ${ }^{8}$

Catherine Martin calls Milton's eclectic treatment of alternative possibilities 'a schema which

permits a maximally dialectical model of divine providence. ${ }^{39}$ That is, the continual

acknowledgement of alternative possibilities refuses to treat providence as rigidly dictated, by

suggesting that potential events still exist in the imagined space of speculation. For this

reason, Anthony Welch rejects Fowler's attempt to determine how many days the action of

Paradise Lost takes: 'the global chronologies of Fowler and others achieved their continuity at

the expense of the reader's actual experience of time in the poem.' $4^{\circ}$ Time, in 'the reader's

actual experience', is splayed and fractured by encyclopedic 'what if's. Milton's investigations

of erroneous fables and things which didn't happen call Thomas Browne’s Pseudodoxia

Epidemica ( I646) to mind. 'To purchase a clear and warrantable body of Truth,' writes

Browne, 'we must forget and part with much that we know'. ${ }^{4}$ Browne is in no hurry to 'forget'

errors though: like Milton lingering over Mulciber's fall, Browne only dismisses an error once

it has been weighed and tested. Browne, like Milton, will treat an error (semi)-seriously before

37 Paradise Lost II.723.

38 Ibid., IV.990-97.

39 Catherine Gimelli Martin, 'The Enclosed Garden and the Apocalypse', in Milton and the Ends of

Time, ed. by Juliet Cummins (Cambridge: Cambridge University Press, 2003), 144-168, p.149.

40 Welch, 'Reconsidering Chronology', p.13.

41 Thomas Browne, Pseudodoxia Epidemica (1646) ed. by Robin Robbins (Oxford: Clarendon, 1981), p. 1. 
refuting it: 'That the Forbidden fruit of Paradise was an Apple, is commonly believed,

confirmed by Tradition, perpetuated by writings, verses, pictures'. ${ }^{22}$ Browne shares with

Burton and Bacon the disinclination to draw conclusions. He views errors from all angles,

analysing their sources and variations. Milton likewise relishes the space in which speculation about the possible truth of error can take place, before common errors are gradually realigned with biblical and experiential truth.

\section{'Earthly notions' and 'the dialect of men'}

The gradual alignment of error with biblical truth and experience is the goal of the discipline known as Biblical accommodation. ${ }^{43}$ Kevin Killeen has said that accommodation makes a

cognitive leap that ... construes aspects of infinity for our comprehension.

[Accommodation] came to inscribe the explanatory spaces between events, to fill in the gaps, and provide the relation-philosophical, scientific, or historical—among biblical events. ${ }^{44}$

Milton is certainly interested in the 'spaces between events', but rather than 'fill[ing] in gaps', he expands and investigates them. I have shown Milton engaged in estranging the natural world with his telescopic vision, and opening up the gaps between fact and error, 'had' and

42 Ibid., p.536.

43 See Neil D. Graves, 'Milton and the Theory of Accommodation', in Studies in Philology 98 (2001): 251-72, and John Reichert, Milton's Wisdom: Nature and Scripture in "Paradise Lost" (Ann Arbour: Michigan University Press, 1992).

44 Kevin Killeen, 'Accommodation in Burnet's Sacred Theory and Paradise Lost', in Milton Studies 46 (2007): 109-113. 
'had not'. He also repeatedly calls attention to the preliminary and make-shift nature of all human discourse. For example:

\begin{abstract}
The palace of great Lucifer (so call
That structure, in the dialect of men

Interpreted $)^{45}$
\end{abstract}

Here Milton uses his familiar technique of suspending possibilities with enjambment. ' $[\mathrm{S}]_{\mathrm{O}}$ call / That structure, in the dialect of men' stands alone as an instruction, until 'Interpreted' on the next line opens up the gap between 'structure' and 'dialect' by showing that to 'call' is to interpret.

The same sentiment is expressed in Milton's famous formulation 'the meaning not the name I call'. ${ }^{6}$ The gap between language and its referents, 'meaning' and 'name', is opened up. Alienation seems a more apposite term than accommodation here, though the two practices, counterintuitively, overlap. As Killeen fully acknowledges in his study of accommodation, the task of 'constru[ing] aspects of infinity for our comprehension' is fraught with hermeneutic problems. To see Milton's interactions with the 'spaces between' things as alienation or estrangement rather than accommodation is less problematic. Like accommodation, alienation calls for "proliferation in interpretation, as an injunction to close

45 Paradise Lost V.760-62. 46 Ibid., VII.5. 
reading, ${ }^{47}$ as Killeen says of accommodation, but it makes sense, in light of the similarities between Milton, Bacon, and Burton, to understand the 'gaps' as deliberately left open, to facilitate 'proliferation' indefinitely.

Milton's Raphael's mode of 'Likening spiritual to corporeal | As may express them best $^{\text {' }}{ }^{8}$ resembles Bacon's pronouncement that 'the subtlety of nature is far greater than that of the human sense and understanding'. Just as seventeenth-century encyclopedists held that there could be no nature 'without the mediating work of the human understanding', so Milton writes

Immediate are the acts of God, more swift Than time or motion, but to human ears Cannot without process of speech be told, So told as earthly notion can receive ${ }^{49}$

'So told as earthly notion can receive' sounds like a 'cognitive leap ... that construes aspects of infinity for our comprehension', but Milton makes it clear that 'process of speech' undoes the very quality that it describes-that is, 'immediacy' is converted into its opposite, 'process'. 'Speech' and 'acts of God' are alienated from, not accommodated to, each other. The distinction between accommodation and alienation is a subtle one, but one worth making. Milton's method does not so much accommodate 'the acts of God' as, by making strange the 47 Killeen, 'Accommodation', p.109. 48 Paradise Lost VII.548. 49 Ibid., VII.176-79. 
'process of speech', force us to consider the mechanisms by which we understand the world, to interrogate them and understand that there are no facts, only interpretations.

Even Milton's conclusion to Paradise Lost eschews conclusiveness. When Adam and Eve leave paradise in the final lines of the poem, 'the world' is 'all before them..$^{\circ}$ They will 'choose their place of rest' physically, but intellectually the vista of 'the world ... all before them' precludes rest. Discussion of the world in the poem has been conducted with 'if's, 'had's, and 'had not's, each one a speculation, never a pronunciation, creating possible, but never definitive, perspectives. The poem ends with yet another new perspective on the world: it is uninhabited, new and unknown. Ending at a beginning, the final lines serve as a reminder of Bacon's warning that to conclude is to 'terminate and extinguish investigation'. To begin to understand their new world, Adam and Eve will have to pose Burtonian 'if's and conduct Baconian speculations, seeking an encyclopedic knowledge that is, by its very nature, always just out of reach. 